\title{
Proteomics and Biological Systems: Application in Oxidative Stress, Nutrition and Prenatal Development
}

\section{Kaïs H Al-Gubory*}

Département de Physiologie Animale et Systèmesd' Elevage, 78350 Jouy-en-Josas, France

${ }^{*}$ Corresponding author: Kaïs H. Al-Gubory, Professor, INRA, UMR 1198 Biologie du Développement et Reproduction, Département de Physiologie Animale et Systèmesd' Elevage, 78350 Jouy-en-Josas, France, Tel: 331 34652362; Fax: 331 34652364;E-mail:kais.algubory@jouy.inra.fr

Received date: Apr 20, 2014, Accepted date: Apr 27, 2014, Published date: Apr 29, 2014

Copyright: ${ }^{\odot} 2014$ Al-Gubory $\mathrm{KH}$, et al. This is an open-access article distributed under the terms of the Creative Commons Attribution License, which permits unrestricted use, distribution, and reproduction in any medium, provided the original author and source are credited.

\section{Editorial}

In biological systems, the genomic approach has emerged to provide a better understanding of the pathophysiological conditions leading to pregnancy-associated disorders and complications, thereby providing a perspective for improving prenatal development outcomes. Nevertheless, it is insufficient to accurately predict protein expression patterns and functions from quantitative messenger RNA [mRNA] due to post-transcriptional regulation mechanisms [mRNA export, surveillance, silencing and turnover] and post-translational modifications which can determine protein activity, localization, turnover and interactions with other proteins [1]. Therefore, investigations of steady-state mRNA expression can only partially predict protein abundances in mammalian cells [2]. In fact, mRNAs are less stable than proteins [3]. In addition, mRNAs are produced at a much lower rate than proteins [4]

Since protein expression is the functional outcome of gene transcription and translation, proteomics, the global study of proteins, has emerged over the last decade to offer a unique means for analyzing the expressed genome under various physiological or pathological conditions in biological systems. Of particular interest to investigators in the field of reproductive medicine is the proteomic approach to measure the secretome, i.e. those proteins that are produced by cells and secreted in biological fluids [5]. Proteomics of biological fluids, including serum, plasma, urine and amniotic fluid, have been employed in human pregnancy research [6] to predict preterm labor and offspring outcomes $[7,8]$ and pregnancy-associated disorders and complications [9-11]. Proteomic analysis of embryonic secretome [12] may provide early prediction markers of embryos with low or high developmental potential.

Imbalance between reactive oxygen species [ROS], by-products of normal cellular metabolism, respiration and energy production in biological systems, and ROS scavenging antioxidants induces oxidative stress that adversely affect parental development and health outcomes [13]. Two-dimensional gel electrophoresis/mass spectrometry-based proteomics approach has greatly facilitated the development of molecular medicine, importantly in the search of antioxidative and oxidative stress biomarkers in reproductive organs. For example, proteomics of the cytotrophoblast of early pregnancy [14], the placenta derived from assisted reproductive technology [15], the corpus luteum [16], and the uterine endometrium $[17,18]$ obtained during the periimplantation period of pregnancy have been used to identify oxidative stress biomarkers and functional redox-sensitive proteins crucial for endometrium receptivity, embryonic implantation and development.

Maternal peri-conception dietary intake and composition are important environmental factors influencing maternal health, and pre and post-natal development outcomes. Proteomics is expected to have an impact in solving malnutrition-associated disorders and pathologies, such as intrauterine fetal growth restriction [19] in association with oxidative stress. In ongoing research focused on the adverse effect of environmental factors-induced oxidative stress on prenatal developmental outcomes, it is important to highlight the role that proteomics can play in identifying protein expression levels and protein modifications mediated by oxidative stress [20]. Proteomics may also provide new insights into antioxidant adaptations mediated in biological systems in response to oxidative stress induced by maternal malnutrition [21], following exposure to various environmental pollutants and/or unhealthy lifestyle behaviors during the peri-conception period [22,23].

Maternal malnutrition and/or exposure to environmental pollutants adversely affect fetal development and subsequent child health outcome. Several of the major diseases of later life find their origins during early prenatal developmental processes in association with oxidative stress induced by environmental factors, mainly periconceptional malnutrition [24] and exposure to a mixture of environmental pollutants and lifestyle behaviors [22]. Many dietary compounds of plant origin with well known significant activity as antioxidants against ROS-induced oxidative damage in biological systems have potential implication in health care and prevention of disease [25]. Therefore, it is necessary to implement potential preventive nutritional antioxidant therapies for populations at high risk for adverse pregnancy outcome. The search for biomarkers of oxidative stress by proteomics in biological fluids could assist in the development and application of nutritional antioxidant therapies against environmental factors-induced oxidative stress and adverse prenatal development and health outcomes.

In the context of the climate changes and the negative impact of global population growth on the environment and natural resources, a large part of the world population will be confronted with maintaining proper nutrition. Maternal food insecurity [26] during the periconception period [27] will be the major challenge to face. International cooperation and joints research projects between public research institutions and private firms, mainly those engaged in agricultural development and food security will be therefore necessary to develop specific tools of prenatal screening and applied nutritional therapies. Therapeutic nutritional strategies must take in consideration women's socioeconomic status. Funding for future research in the field of nutrition, environmental pollution and health should be directed into the epidemiological and preventive studies instead of experiments on animals. 


\section{References}

1. Mann M, Jensen ON (2003) Proteomic analysis of post-translational modifications. Nat Biotechnol 21: 255-261.

2. de Sousa Abreu R, Penalva LO, Marcotte EM, Vogel C (2009) Global signatures of protein and mRNA expression levels. Mol Biosyst 5: 1512-1526.

3. Sharova LV, Sharov AA, Nedorezov T, Piao Y, Shaik N, et al. (2009) Database for mRNA half-life of 19977 genes obtained by DNA microarray analysis of pluripotent and differentiating mouse embryonic stem cells. DNA Res 16: 45-58.

4. Vogel C, Marcotte EM (2012) Insights into the regulation of protein abundance from proteomic and transcriptomic analyses. Nat Rev Genet 13: 227-232.

5. Hathout Y (2007) Approaches to the study of the cell secretome. Expert Rev Proteomics 4: 239-248.

6. Shankar R, Gude N, Cullinane F, Brennecke S, Purcell AW, et al. (2005) An emerging role for comprehensive proteome analysis in human pregnancy research. Reproduction 129: 685-696.

7. Buhimschi IA, Buhimschi CS (2008) Proteomics of the amniotic fluid in assessment of the placenta. Relevance for preterm birth. Placenta $29 \mathrm{Suppl}$ A: S95-101.

8. Di Quinzio MK, Georgiou HM, Holdsworth-Carson SJ, Ayhan M, Heng YJ et al. (2008) Proteomic analysis of human cervico-vaginal fluid displays differential protein expression in association with labor onset at term. J Proteome Res 7: 1916-1921.

9. Ferrero S, Gillott DJ, Remorgida V, Anserini P, Leung KY, et al. (2007) Proteomic analysis of peritoneal fluid in women with endometriosis. J Proteome Res 6: 3402-3411.

10. Buhimschi IA, Zhao G, Funai EF, Harris N, Sasson IE, et al. (2008) Proteomic profiling of urine identifies specific fragments of SERPINA1 and albumin as biomarkers of preeclampsia. Am J Obstet Gynecol 199: 551.

11. Romero R, Espinoza J, Rogers WT, Moser A, Nien JK et al. (2008) Proteomic analysis of amniotic fluid to identify women with preterm labor and intra-amniotic inflammation/infection: the use of a novel computational method to analyze mass spectrometric profiling. J Matern Fetal Neonatal Med 21: 367-388.

12. Katz-Jaffe MG, McReynolds S, Gardner DK, Schoolcraft WB (2009) The role of proteomics in defining the human embryonic secretome. Mol Hum Reprod 15: 271-277.

13. Al-Gubory KH, Fowler PA, Garrel C (2010) The roles of cellular reactive oxygen species, oxidative stress and antioxidants in pregnancy outcomes. Int J Biochem Cell Biol 42: 1634-1650.

14. Hoang VM, Foulk R, Clauser K, Burlingame A, Gibson BW, et al. (2001) Functional proteomics: examining the effects of hypoxia on the cytotrophoblast protein repertoire. Biochemistry 40: 4077-4086.
15. Zhang Y, Zhang YL, Feng C, Wu YT, Liu AX, et al. (2008) Comparative proteomic analysis of human placenta derived from assisted reproductive technology. Proteomics 8: 4344-4356.

16. Arianmanesh M, McIntosh RH, Lea RG, Fowler PA, Al-Gubory KH (2011) Ovine corpus luteum proteins, with functions including oxidative stress and lipid metabolism, show complex alterations during implantation. J Endocrinol 210: 47-58.

17. Domínguez F, Garrido-Gómez T, López JA, Camafeita E, Quiñonero A, et al. (2009) Proteomic analysis of the human receptive versus non-receptive endometrium using differential in-gel electrophoresis and MALDI-MS unveils stathmin 1 and annexin A2 as differentially regulated. Hum Reprod 24: 2607-2617.

18. Al-Gubory KH, Arianmanesh M, Garrel C, Bhattacharya S, Cash P, et al. (2014) Proteomic analysis of the sheep caruncular and intercaruncular endometrium reveals changes in functional proteins crucial for the establishment of pregnancy. Reproduction 147: 599-614.

19. Wang J, Li D, Dangott LJ, Wu G (2006) Proteomics and its role in nutrition research. J Nutr 136: 1759-1762.

20. Grimsrud PA, Xie H, Griffin TJ, Bernlohr DA (2008) Oxidative stress and covalent modification of protein with bioactive aldehydes. J BiolChem 283: 21837-21841.

21. Al-Gubory KH (2013) Maternal nutrition, oxidative stress and prenatal developmental outcomes.

22. Al-Gubory KH (2014) Environmental pollutants and lifestyle factors induce oxidative stress and poor prenatal development. Reprod Biomed Online.

23. Al-Gubory KH (2014) Reactive oxygen species, antioxidant systems and prenatal developmental outcomes. In Handbook: Systems Biology of Free Radicals and Anti-Oxidants. Editor Ismail Laher. Springer-Verlag, Germany.

24. Luo ZC, Fraser WD, Julien P, Deal CL, Audibert F, et al. (2006) Tracing the origins of "fetal origins" of adult diseases: programming by oxidative stress? Med Hypotheses 66: 38-44.

25. Liu RH (2013) Dietary bioactive compounds and their health implications. J Food Sci 78 Suppl 1: A18-25.

26. Carmichael SL, Yang W, Herring A, Abrams B, Shaw GM (2007) Maternal food insecurity is associated with increased risk of certain birth defects. J Nutr 137: 2087-2092.

27. Ramakrishnan U, Grant F, Goldenberg T, Zongrone A, Martorell R (2012) Effect of women's nutrition before and during early pregnancy on maternal and infant outcomes: a systematic review. Paediatr Perinat Epidemiol 26 Suppl 1: 285-301. 